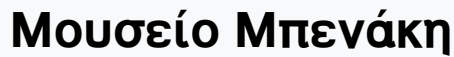

Tóp. 3 (2003)

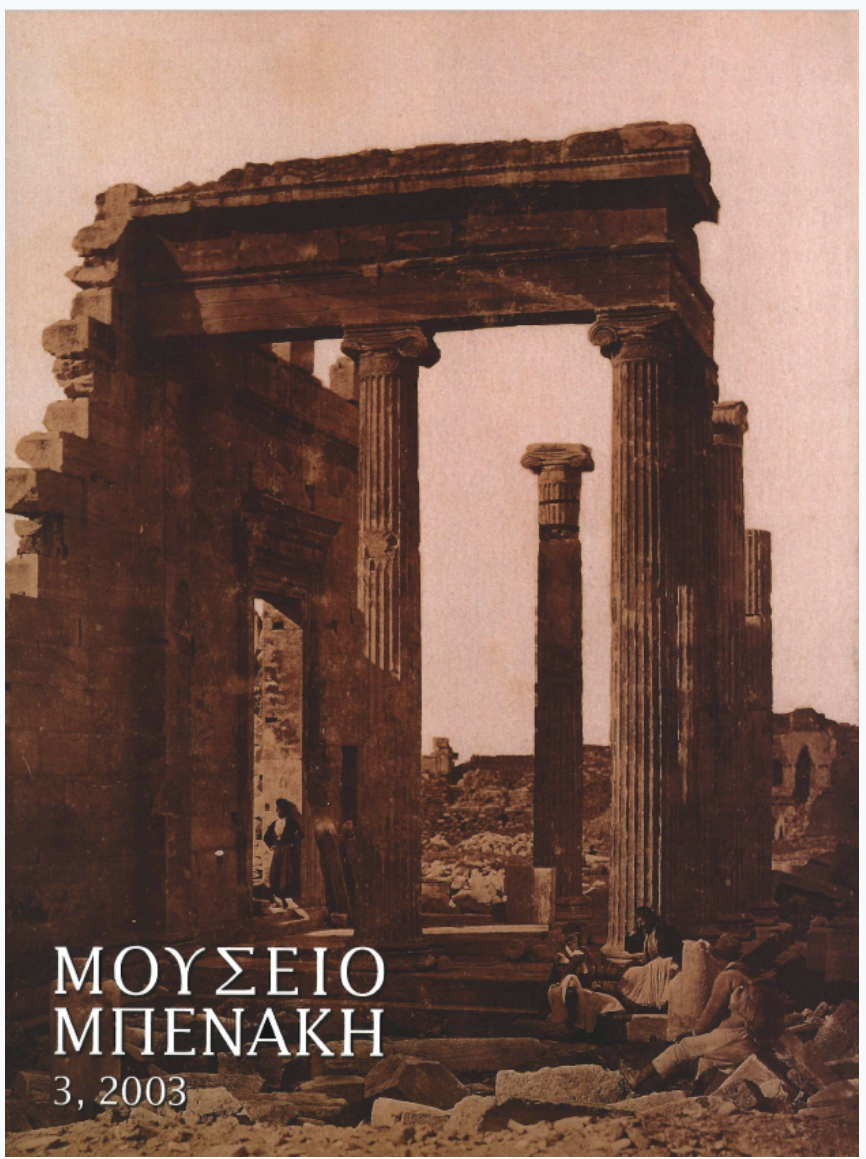

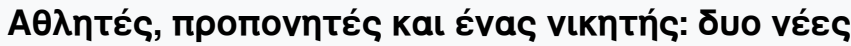

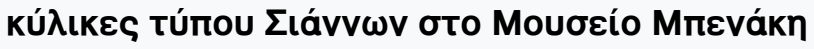

\section{Maria Pipili}

doi: $10.12681 /$ benaki.18204

\section{Copyright $\odot$ 2018, Maria Pipili}

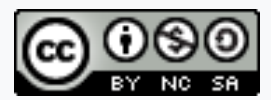

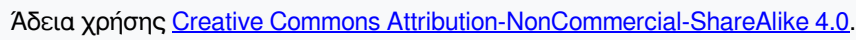

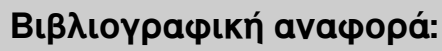

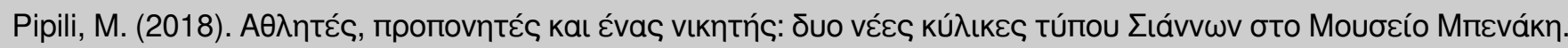

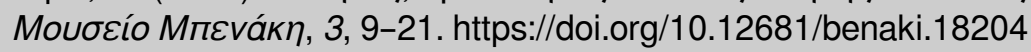




\section{Athletes, trainers and a victor: two new Siana cups in the Benaki Museum}

THE TWO CUPS presented here belong to the main type of Attic black-figure cup in the second quarter of the sixth century BC, the Siana cup, named after a village in Rhodes where two such examples were found. ${ }^{1}$ Their provenance is unknown. They were both donated to the Benaki Museum by Mrs Peggy Zoumboulaki and it is possible that they were found together; although they were not produced in the same workshop, they are roughly contemporary and are also related iconographically, since they are both decorated with athletic scenes. Some of these scenes present a particular interest as they rank among the earliest of their kind, and one is even unique in the archaic iconographic repertoire.

The first cup (inv. no. 31130) (figs 1-4) has been mended from many fragments. Several pieces of the lip and bowl, as well as both handles, are missing and have been restored in plaster. There is some repainting on the inside (border of tondo, elbow of man, tip of his spear). The black glaze is shiny. There are additions in red and white which are well preserved.

The inside of the cup (fig. 1) is glazed except for a reserved line near the edge of the lip, and the tondo which is decorated with a naked man who runs towards the right with his head turned backwards; in his lowered right hand he holds a spear horizontally and he raises his left hand. The tondo is bordered by a band of tongues, alternately black and red, within triple glaze lines. The outside is decorated in the overlap system, i.e. with the figured decoration extending on both lip and handlezone. There is a glaze line along the edge of the lip and another at the junction of lip and bowl. The lower bowl is glazed except for a decorative band of base-rays. The foot is glazed, with a reserved resting surface which is decorated with a glaze circle.

Side A (fig. 2) shows athletes training. From left to right, we see a naked youth who moves to the right, a wrap hanging over his raised left arm; a discus-thrower facing right who holds a discus in his lowered right hand and raises his left hand (there is a drop of paint above his head and another in front of his raised arm); a draped man, probably a trainer, facing left; a javelin-thrower facing right; a naked man with a wrap draped over his raised left arm who moves to the right and looks round. Between this figure and the previous one there is a red object, probably a garment hanging on the wall.

Side B (fig. 3) is decorated with horsemen and men. From left to right, there is a draped male figure (upper part missing) standing and facing right; a naked man with a wrap draped over his raised left arm striding to the right; a youth on horseback wearing a short chiton and holding a stick in his right hand galloping to the left; in the field behind the rider, a bird flying to the left; a draped male figure standing facing left and extending one arm; a second horseman (upper part missing) galloping to the left.

Red: On the inside, man's hair and beard. On side $A$, hair and beard of discus-thrower, trainer and javelinthrower; vertical fold of wrap of youth on the far left; parts of himation of trainer; wrap of man on the far right; cloth hanging on wall. On side $\mathrm{B}$, hair and beard of man facing the central horseman; dots on himation of man standing on the far left and fold over his left 


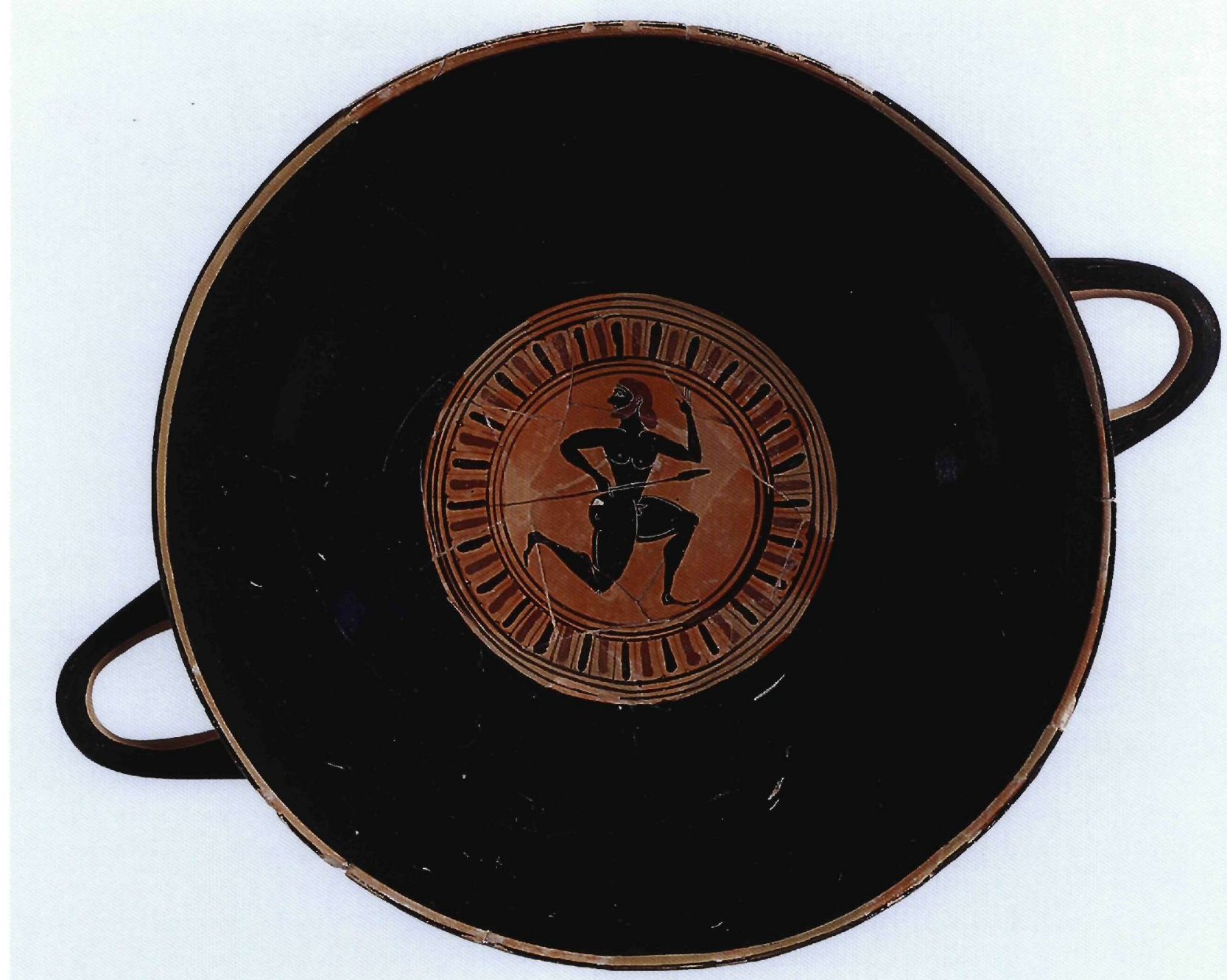

Fig. 1. Siana cup (interior). Athens, Benaki Museum 31130 (photo: K. Manolis).

forearm; wrap of man facing the horseman; himation of figure following the horseman; neck of central horse and stripe on its hindquarters; wings of bird. White: On side A, dot-rosettes on wrap of youth on the far left.

The cup has been attributed by Brijder to the Malibu Painter, ${ }^{3}$ a member of the C Painter's workshop, which was one of the most prolific producers of Siana cups. Together with his close colleague, the Taras Painter, he seems to have joined the workshop during the middle phase of the C Painter's career, around $565 \mathrm{BC}$, and was active until about $550 \mathrm{BC} .{ }^{4}$ Our cup was dated by Brijder around $560 \mathrm{BC}$, in the Malibu Painter's middle period. It is a large cup, as are most cups of the painter's middle and late periods. Its shape (fig. 4), with a lip which does not project too much, a curved shoulder and a rather rounded body, is quite common in the $\mathrm{C}$ Painter's workshop, occurring at all periods in the products of most of the artists who worked there. ${ }^{5}$ The simple band of tongues bordering the tondo is used frequently not only by the Malibu Painter, but also by the other artists in the C Painter's workshop. On the Benaki cup it is rather narrow and framed by three glaze circles, ${ }^{6}$ a type which occurs mainly on cups of the Malibu Painter's late period, i.e. the decade 560-550 BC. Base-rays, usu- 

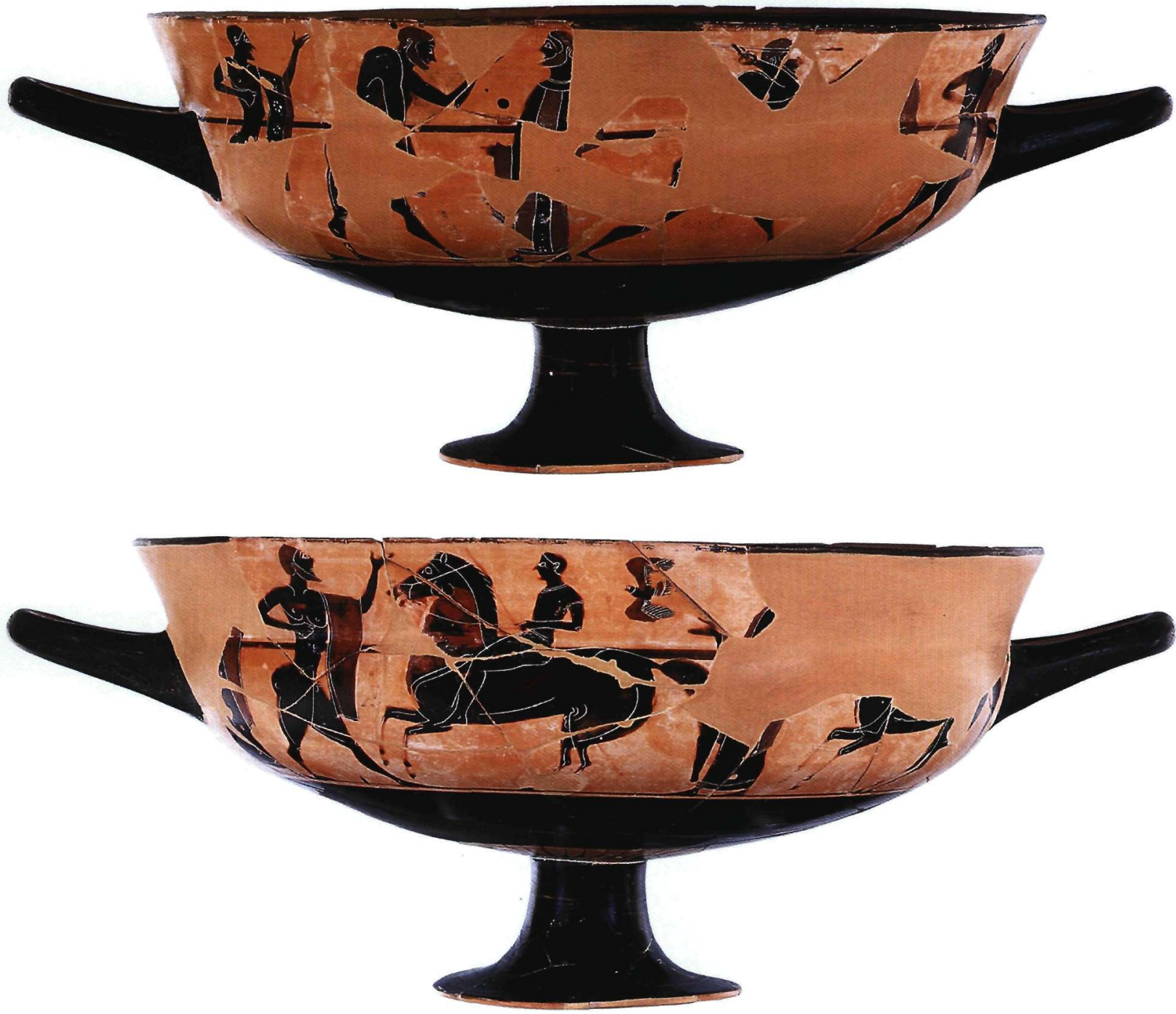

Figs 2-3. Siana cup. Athens, Benaki Museum 31130 (photo: K. Manolis).

ally with a band of dots above them, occur as a rule on the painter's double-deckers, ${ }^{7}$ i.e. those cups which have a two-row decoration on the outside, and only rarely on his overlap cups, the few examples of which are all from the painter's late period. ${ }^{8}$ Our cup may, therefore, belong to the beginning of the painter's late period, i.e. to the years just after $560 \mathrm{BC}$.

Most of the Malibu Painter's cups have almost identical pictures on both sides. On the cup in the Benaki Museum the scenes are not the same, but they are closely related since they both deal with athletics. On side A (fig. 2) we have a discus-thrower and a javelin- thrower among draped or naked men and youths in what is probably intended as a scene in a gymnasium. The athletes on our cup are among the earliest of their kind in ancient Greek vase-painting. Before 550 BC there are only three other discus-throwers on vases, two of them on Siana cups, ${ }^{9}$ and three other javelin-throw-. ers, two of them on Sianas. ${ }^{10}$ All works date from the decade 560-550 BC. Only two of these early vases, the Benaki cup and a Siana cup by the Heidelberg Painter in Amsterdam, combine a discus-thrower and an acontist, something quite common on later vases. ${ }^{11}$ The discusthrower on the Benaki cup stands with legs far apart and 


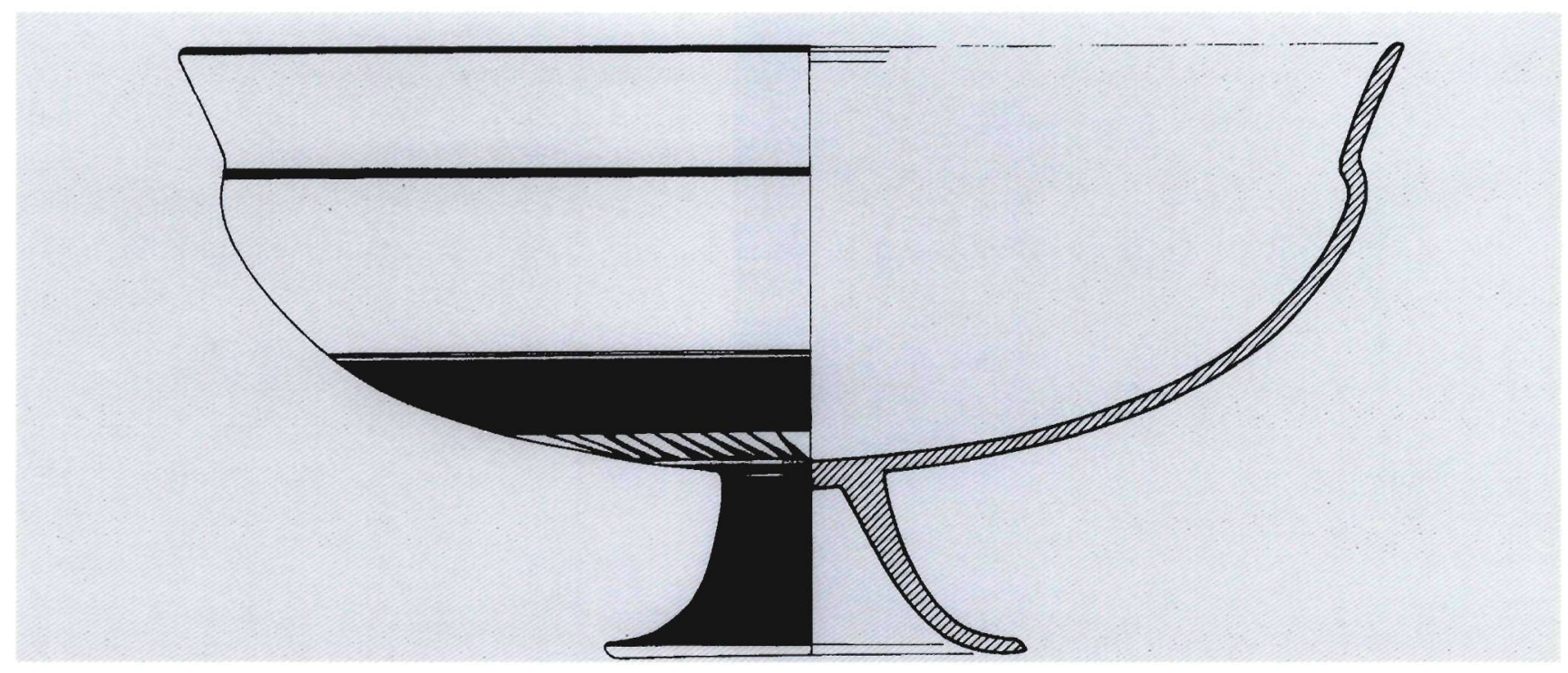

Fig. 4. Profile drawing of Siana cup. Athens, Benaki Museum 31130, scale 1:2 (drawing: A. Dringopoulou).

both arms extended forward; the right arm is lowered with the discus resting flat in the hand, while the left arm is raised. This pose, which is the most common in the earliest period, is regarded as one of readiness before the back swing and throw. ${ }^{12}$ Almost all vases from the decade after the middle of the sixth century show the acontist in a slightly different pose, i.e. with the left arm brought back -either lowered or raised-in what is regarded as the beginning of the backward swing. ${ }^{13}$ The discus is always shown foreshortened, in three-quarter view, and this is remarkable for the early works. ${ }^{14}$ The javelin-thrower on our cup steps forward, holding the javelin horizontally at head level. His fingers are inserted in the ankyle, the loop made from a strip of leather wrapped around the centre of the javelin shaft which was used as a throwing-aid. ${ }^{\text {is }}$ The two athletes on the Benaki cup are the only discus-thrower and acontist known so far to have been produced in the C Painter's workshop. Other athletic events, however, like wrestling and boxing, and above all horse-racing, occur on several Siana cups by the $\mathrm{C}$ Painter and his most prominent younger colleagues, the Taras Painter and the Malibu Painter. ${ }^{16}$ From the late 560s onwards there is a growing interest in depicting sporting scenes on vases in general, and this has been associated with the reorganization of the Panathenaic Games, traditionally dated 566/565 BC, when it seems that gymnastic and equestrian contests were added to the festivities, of which they would remain a very important part. ${ }^{17}$ Moreover, just a few years earlier three Panhellenic athletic festivals (the Pythian, the Nemean and the Isthmian) had been instituted on the model of the games at Olympia. ${ }^{18}$ The development of sport at that time brought with it an improvement in athletic facilities and the need for professional trainers who would supervise the athletes' exercise. ${ }^{19}$ Trainers are often shown on vases, usually as elderly draped figures watching the athletes closely, often holding sticks; but it is not always easy to distinguish them from mere spectators, judges or other officials. On the Benaki cup the draped man standing opposite the discus-thrower watching him closely could well be a trainer. There are two more bystanders, a youth on the far left and a bearded man on the far right, both naked but for a chlamys draped over their left upper arm, who seem to show a vivid interest in what is going on: they raise a hand as if to encourage the athletes in their efforts. It is not easy to tell, however, if they are fellow athletes, trainers or simple onlookers. What we can say is that they belong to the iconographic stock of the C Painter's workshop, since they appear in an almost identical form in several scenes -athletic or other- produced in this workshop. ${ }^{20}$

Side B of the Benaki Museum vase (fig. 3) shows horsemen, a very popular subject on Siana cups by the C Painter and his closest colleague, the Taras Painter, 
but also more generally in ancient Greek vase-painting, which favoured scenes connected with the activities of aristocratic citizens. The horsemen who are dressed in short chitons and carry spears are usually regarded as cavalrymen, and the naked youthful riders who either do not hold anything or are equipped with short sticks, as jockeys. ${ }^{21}$ The latter may be shown either galloping in a race or a training-session, or riding quietly in the company of youths, men and women, many of whom raise their hand in greeting. In the latter case they are usually interpreted as victorious athletes received by their family, friends, trainers and perhaps the owners of the horses. ${ }^{22}$ Associated with this scene is another one where youths who often raise a hand in a gesture of greeting are shown together with men and women. The scene, which is very frequent in the work of the Taras Painter, has been interpreted as the return of victorious athletes, although none of the youths is clearly characterized as a victor. ${ }^{23}$ The scene on side $\mathrm{B}$ of the Benaki Museum cup is the Malibu Painter's only version of the so-called 'return from the horse-race', a theme which is treated twice by the C Painter and very often by the Taras Painter where the riders are usually welcomed by women. ${ }^{24}$ The jockeys on the Malibu Painter's cup, unlike those by the $\mathrm{C}$ Painter and the Taras Painter who are naked and do not hold anything, are dressed in chitoniskoi and carry thin sticks. ${ }^{25}$ As for the horses, these are not standing or advancing quietly, as always in this type of scene, but galloping among the spectators. This is not found elsewhere, and we may wonder whether the artist did not intend to show horsemen training for the race, in which case the scene would be a counterpart of the scene on the other side which shows two athletes training in a gymnasium. We should note that the bystanders are very similar to those on side A: we again have a naked man with a wrap hanging over his arm who gesticulates in a lively manner -a trainer or an excited spectator- as well as two draped men standing quietly and holding out one hand.

The naked man with a spear who is shown in a kneeling-running posture on the interior of the cup (fig. 1) is a puzzle. Typologically he is close to the image of a running warrior who looks round as if pursued on the interior of several cups by the Malibu Painter. ${ }^{26}$ These warriors, however, are always wearing a helmet (or a pilos) and greaves, and carry a shield as well as the spear. There is only one example of a warrior who is bare-headed and does not carry a shield, on a cup once on the New York Market, which offers the closest parallel to our figure. ${ }^{27}$ But this figure, who is dressed in chiton and chlamys, wears greaves, while the man on the Benaki cup has nothing but the spear to characterize him as a hoplite. Now, the spear may be held not only by hoplites in full armour but also by civilians who are otherwise unarmed. On vases by the Heidelberg Painter and the Amasis Painter, for example, we often have draped spear-bearers -presumably upper-class citizens- flanking a central scene, or participating in social encounters. ${ }^{28}$ In the $\mathrm{C}$ Painter's workshop we may also have civilians (of a different type to those by the Heidelberg Painter) holding a spear. In one of the Taras Painter's favourite gatherings of youths, men and women (a scene which, as we saw, has been interpreted as the return of athletes) we have a naked youth carrying a spear on his shoulder, ${ }^{29}$ and in another, a naked man with a wrap draped over his arm holding a spear..$^{30}$ The running man on the interior of our cup is to be compared to these figures more than to any others, in spite of the fact that the artist has used here his favourite compositional type of a warrior who runs holding a spear horizontally as if ready to attack. Another possibility is that this is an athlete, something expected on the interior of a cup both sides of which deal with sport. The javelin did not usually have a sharp metal point, unless used for throwing at a set target, an equestrian event which seems to have been introduced later in antiquity; but there are a few vases contemporary to ours -one of them a recently published Siana cup fragment by the Heidelberg Painter- where javelins used for throwing at a distance, as indicated by the presence of a thong, have the form of a spear. ${ }^{31}$

We now come to the second Siana cup in the Benaki Museum which will be discussed here. This cup (inv. no. 31131) (figs 5-9) 32 $^{32}$ has also been mended from several fragments. Some pieces of lip and bowl, half of one handle and the entire foot are missing and have been restored in plaster. There is some repainting (border of tondo, parts of women and right leg of Theseus on side $B$, part of rays on lower part of bowl). The surface has flaked in many places, especially on the lip of side B. The black glaze is of very bad quality; it has misfired a reddish brown on the inside, and is red to reddish brown 


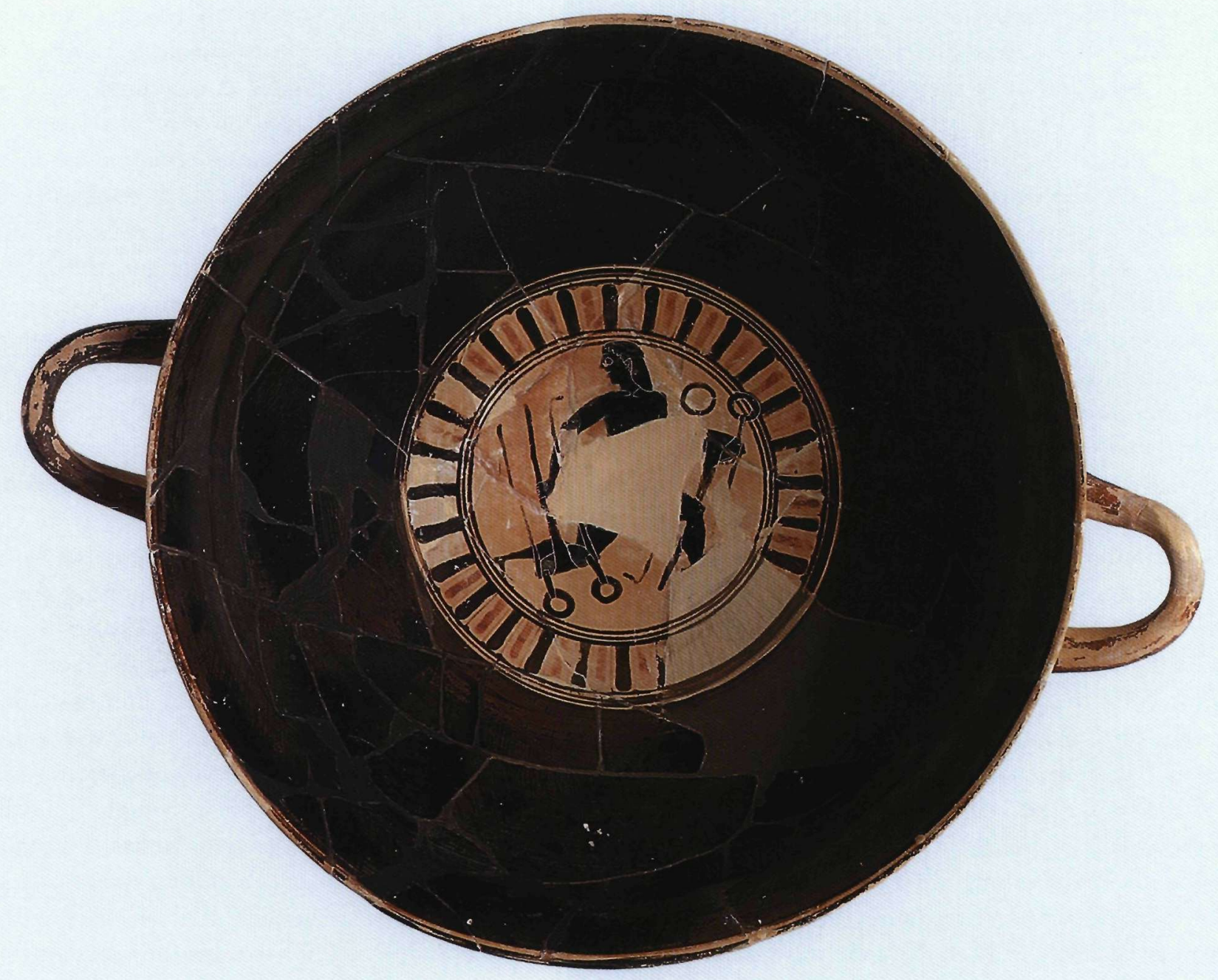

Fig. 5. Siana cup (interior). Athens, Benaki Museum 31131 (photo: K. Manolis).

on the right part of side $\mathrm{A}$, on the left part of side $\mathrm{B}$, and on the handle in between. There are additions in red and white which have disappeared in many places.

The inside (fig. 5) is glazed, apart from a reserved line along the edge of the lip and the tondo which is decorated with a naked youth who runs to the right looking back, carrying two tripods, one in each hand. The tondo is framed by a band of tongues, alternately black and red, within triple glaze lines. The outside is decorated in the overlap system. There is a glaze line at junction of lip and bowl. Under the ground line there is a glaze band and below it a band of rays.
Side A (fig. 6) shows three young horsemen galloping to the right, wearing short chitons and holding thin sticks. The first horseman, on the far right, looks round; behind him a naked man runs to the right looking back, holding the reins of the second horse with his right hand and a stick in his raised left hand. On the far left there is a bird flying to the right.

On side B (fig. 7) we see Theseus attacking the Minotaur between onlookers. In the centre, Theseus, who is bearded and wears a short chiton and a skin on top, strides to the right. He grasps the Minotaur's left wrist with his own left hand and thrusts his sword into the 

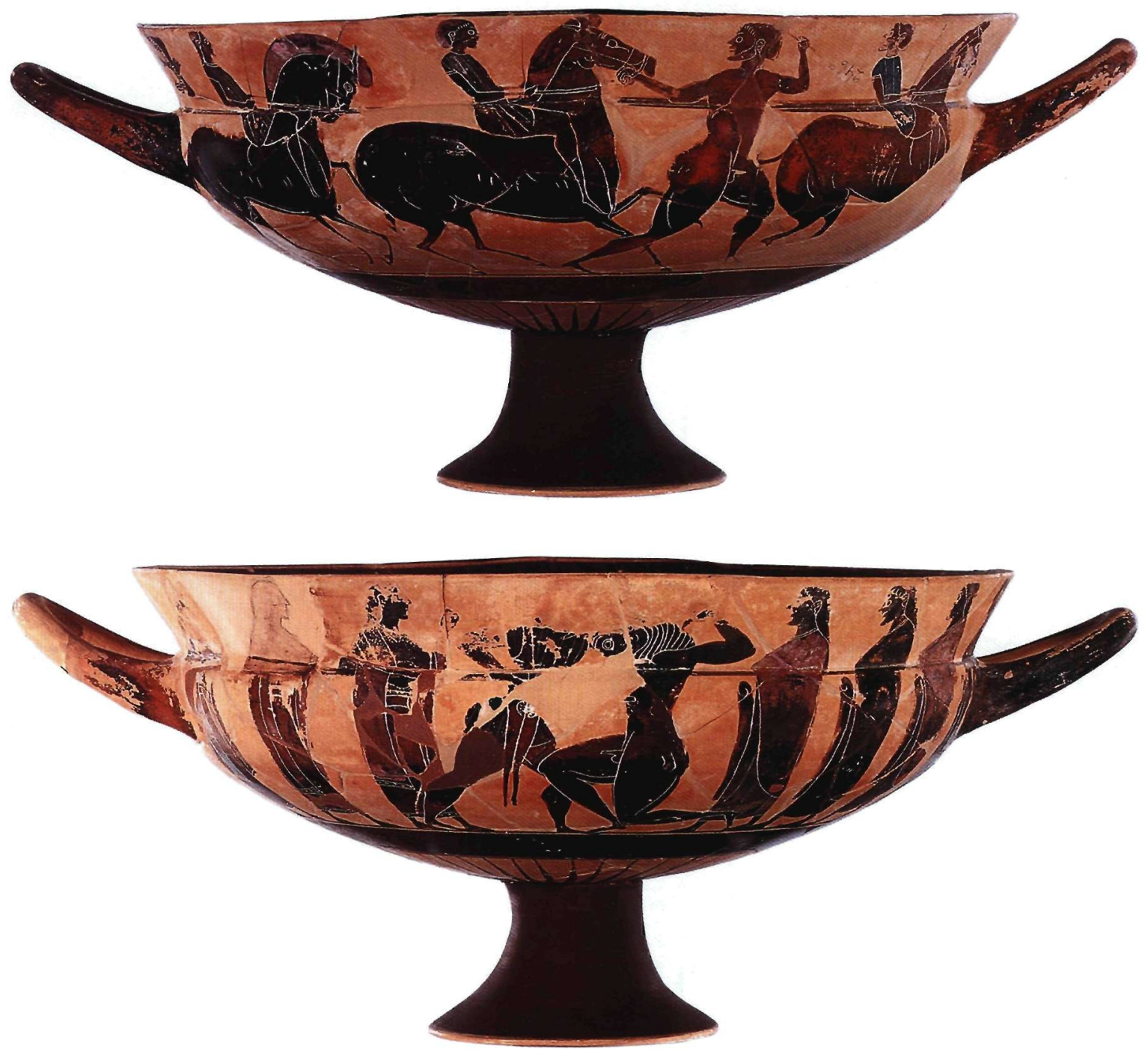

Figs 6-7. Siana cup. Athens, Benaki Museum 31131 (photo: K. Manolis).

Minotaur's chest (only the tip of the sword is preserved). The Minotaur collapses on his left knee. He has a tattoo of five parallel rows of dots painted on his left thigh and holds a stone in each hand (the left hand has flaked leaving only some traces of a round fist; the right hand, shown as a circle with a white patch inside indicating the stone, is visible on Theseus' animal skin, at waist level). The central group is flanked by spectators: three women in belted peploi and himatia on the left and four youths in chitons and himatia on the right. The woman immediately behind Theseus raises her left hand. The upper part of the woman who follows her is lost (the missing fragment has been restored in plaster and the silhouette of the figure repainted).

Red: On side A, hair of horsemen and manes of horses. On side B, himatia of all women and dots on peplos of middle one; himatia of first and third youth and dots on chiton of second one; hair-bands of youths. White (not preserved): On the interior, bowls of both tripods and dots on middle leg of one. On side A, chitons of riders. On side $\mathrm{B}$, chitons of first, third and fourth youth standing behind the Minotaur, and dots on himation of second youth; tattoo on Minotaur's thigh.

The shape and secondary decoration of this cup are 


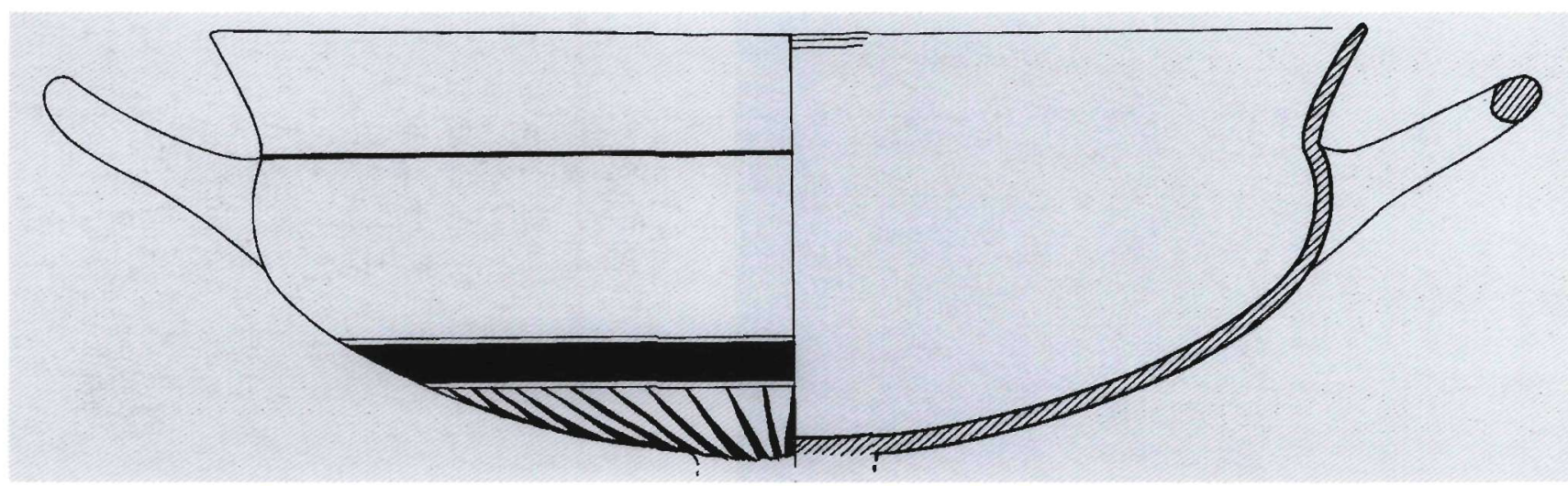

Fig. 8. Profile drawing of Siana cup. Athens, Benaki Museum 31131, scale 1:2 (drawing: A. Dringopoulou).

not too far apart from those of the first cup discussed here, but the straight lip is turned much more markedly outwards and the bowl is shallower (fig. 8). The shape is not unknown to the $C$ Painter's workshop, to which the horsemen of side $\mathrm{A}$ are also close. The style of drawing, however, does not allow us to attribute it to any of the known painters of this workshop. According to Brijder, our cup has something in common with the style of the Painter of Boston C.A., and might be a work of a follower. ${ }^{33}$ Of the known Sianas, one which is stylistically very close to ours is a cup in Thebes which shows on both sides horsemen surrounded by men and women, a composition interpreted as 'the return from the horserace'. ${ }^{34}$ The faces of the figures with their fringed hair and pointed noses and chins are similar on both works, although on our cup the noses and chins are not as prominent. Also, on both works the men's hands which are concealed under their himatia and held in front of their bodies are rendered with the same small incised curves (more cursorily drawn on our cup), and there are further similarities like the vertical incised lines on the men's chitons, and the drawing of the horses. Very close to the cup in Thebes is another Siana cup in Cleveland which has been attributed to the same hand..$^{35}$ Our cup is probably a product of the same workshop and should be dated in the decade 560-550 BC.

The scene on side A (fig. 6) deals with horse-racing. ${ }^{36}$ The youths are dressed in short chitons and carry sticks like the jockeys on the Malibu Painter's cup. Here, however, we have no draped men or youths standing between the horses, but just a naked man who runs alongside a horse holding its reins with his right hand and a stick in his raised left hand. This detail, as well as the fact that he is the only bearded figure among the young horsemen, indicates that he is a trainer of jockeys, and the scene a training session, as is possibly also the case with the scene on side B of the other Benaki cup that we saw. ${ }^{37}$

The struggle of Theseus and the Minotaur shown on side B (fig. 7) is one of the earliest representations of the theme in Attic vase-painting where the subject first appears in the decade $560-550 \mathrm{BC} .^{38}$ It is rarely depicted on Siana cups: apart from the Benaki cup, there are only three others, all slightly later than ours, showing the theme. ${ }^{39}$ These cups come from different workshops and do not use the same iconographic scheme. Two of the cups show the Minotaur confronting Theseus, while the other two show him trying to flee. ${ }^{40}$ In no other Siana cup does Theseus stretch out his left hand to restrain the left hand of the Minotaur, a scheme which is very popular on Attic vases. Our cup also differs from the others in that it shows Theseus bearded, something not unexpected, however, since Theseus is often bearded in early works. As for the way the Minotaur is shown, all Siana cups depict him holding stones in both hands, as very frequently in art; ${ }^{41}$ but not all painters were of one mind about whether the monster had a tail or not. ${ }^{42}$ The tattoo-mark on the Minotaur's thigh on the Benaki cup occurs in exactly the same place on some Attic vases, ${ }^{43}$ so must have belonged to some early iconographic model. The meaning of such dots which are painted or incised on the bodies of some figures (especially warriors, heroes or monsters) is rather obscure. ${ }^{44}$ The youths and women 
flanking the scene might refer to the Athenian tribute of youths and maidens who were to be fed to the Minotaur. The woman behind Theseus who raises a hand might be Ariadne but she is otherwise not differentiated from the other women.

The image on the interior of the cup (figs 5, 9) brings us back to the world of sport. A naked youth who runs to the right and looks round is shown carrying two tripods, one in each hand. The image of the tripod-bearer is not unknown to archaic vase-painting, occurring on a fair number of vases from the second quarter of the sixth century $\mathrm{BC}$ on. ${ }^{\text {is }}$ The earliest such scene is on a Siana cup by the C Painter dated about 570-565 BC where a man in short chiton carrying a tripod on his head is received by draped men who stand on either side. ${ }^{46}$ The Benaki cup offers the second representation of a victorious athlete carrying his prize, since all other such scenes belong to the years after 550-540 BC. Sometimes the prize is carried not by the victor, but by a follower who walks behind him, ${ }^{47}$ but in our case a single naked figure in a tondo cannot be anyone else but the victorious athlete himself. Our painter did not follow the usual iconographic scheme for this type of image, i.e. the tripod being carried on the head, often with much effort. He has shown a youth carrying with great ease not one, but two tripods, one in each hand. The tripods are much smaller than those in most other scenes, where they are usually life-size, but this may have been imposed by the restricted space of the tondo. ${ }^{48}$ The depiction of two tripods carried by a single person is, as far as we know, unique in the iconography of the subject. Is the youth shown as a victor in two athletic events? Or did the artist want to emphasize the notion of victory by duplicating the prize? The latter seems more probable, and we may think here of the large number of tripods shown next to some athletic scenes in order to stress their agonistic character. ${ }^{49}$ There is no point in trying to find out what victory the young man on our cup won, since the artist does not give us any hint of this, and seems just to be interested in depicting a victor.

If the two vases in the Benaki Museum discussed here were found together, as their related iconography and

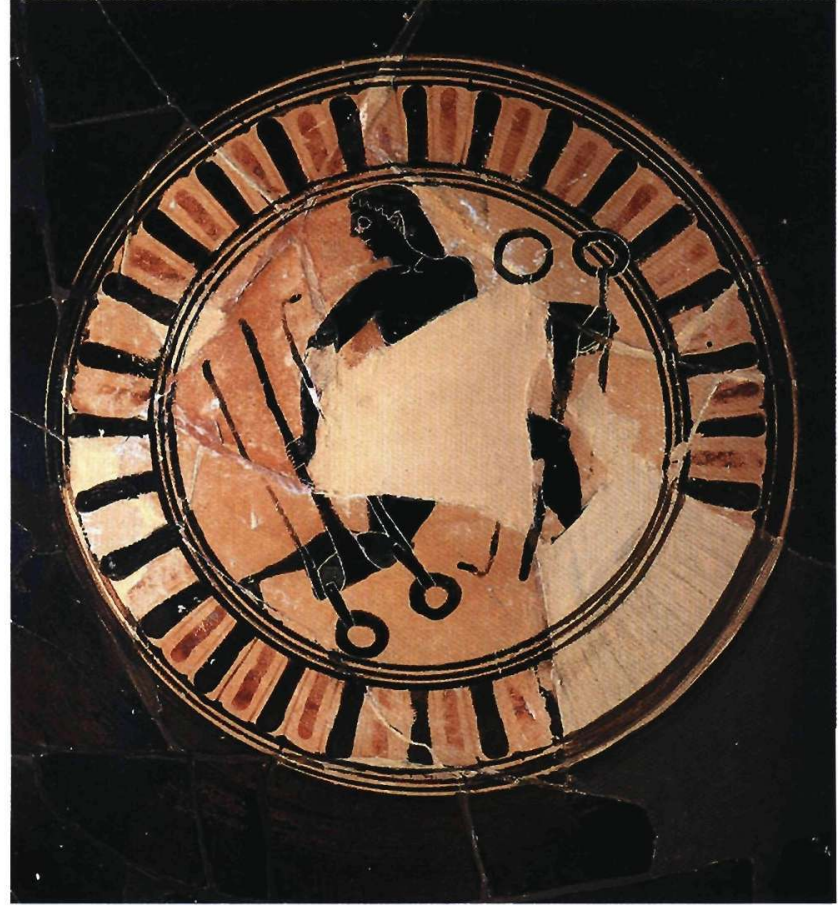

Fig. 9. Tondo of Siana cup. Athens, Benaki Museum 31131 (photo: K. Manolis).

contemporary manufacture seem to suggest, we may suppose that they were owned by someone who had some association with athletics, for example an aristocrat who kept and raced horses, or a pentathlon athlete, since pottery was often commissioned for the symposion after an athletic victory. ${ }^{50}$ In any case, it must have been someone who would have been interested in the scenes from the world of sport so amply depicted on the two cups, and for whom the image of the victorious youth carrying his prizes would have been a personification of his own athletic achievements or aspirations.

Maria Pipili

Academy of Athens

Research Centre for Antiquity

14. Anagnostopoulou Str.

GR-106 73 Athens

e-mail:pipili@academyofathens.gr 


\section{ABBREVIATIONS}

Brijder 1983: H. A. G. Brijder, Siana Cups I and Komast Cups (Amsterdam 1983).

Brijder 1991: H. A. G. Brijder, Siana Cups II: The Heidelberg Painter (Amsterdam 1991).

\section{Notes}

* I am most grateful to Prof. A. Delivorrias for inviting me to publish the black-figure vases of the Benaki Museum, a work which is under preparation. I should also like to thank $\mathrm{H}$. Brijder for sharing with me his unequalled knowledge of Siana cups, M. Tiverios for discussions, B. Stassinopoulou for her friendly assistance, and, most especially, I. Papageorgiou for her invaluable help at the Benaki Museum. The photographs are by K. Manolis and the drawings by A. Dringopoulou.

1. For Siana cups the standard work is Brijder's meticulous multi-volume study of all the known examples: Brijder 1983; Brijder 1991; Brijder 2000. A fourth volume is under preparation.

2. Height, $13.6 \mathrm{~cm}$; diameter of $\operatorname{rim}, 27 \mathrm{~cm}$; diameter of foot, $9.2 \mathrm{~cm}$.

\section{Brijder 2000, 669, 724, add. no. 14 .}

4. For the Malibu Painter see Brijder 1983, 169-81; 255-59 nos. 216-52. Additional vases in Brijder 1991, 481-82 nos. 1-10; Brijder 2000, 669, 723-24 nos. 11-17. Most of the works attributed by Brijder to the Malibu Painter had been assigned by Beazley to the $C$ Painter or to his manner. The need to create new painters from the work of a well-known one was questioned by some reviewers (D. C. Kurtz, CR 35 [1985] 345; T. H. Carpenter, JHS 106 [1986] 252; D. von Bothmer, Gnomon 59 [1987] 716-21). The Malibu Painter's style of drawing is very close to that of the C Painter, but, as in the case of the Taras Painter, there is no doubt that we have here a distinct artistic personality. Apart from Sianas, the Malibu Painter decorated some other shapes: three lekythoi, a "pilgrim-flask" and a skyphos (Brijder 1983, 169 n. 492).

5. Cf. the C Painter's cups Brijder 1983, no. 58 pl. 75 (middle period); no. 117 fig. 33 (late period); also, the Taras Painter's, ibid. no. 133 pl. 81 (early period) and no. $149 \mathrm{pl}$. 82 (middle period). The shape of the foot is also common in the C Painter's workshop (see, e.g., the Taras Painter's, ibid. no. 149 pl. 82 and no. 195 pl. 85 ).

6. Brijder 1983, 172 fig. 55 d.

7. Brijder 1983, 174-75 fig. 57 a-b.

8. Brijder 1983, no. 237 pl. 43b; no. 246 pl. 43 c-d; no. 247 pl. 44 a-b; Brijder 1991, 482 no. 5 pl. 165 a-c.

9. (a) Boeotian tripod pyxis, Berlin 1727: ABV 29,1; CVA 4, pl. 197,7; (b) Siana cup, Amsterdam 10.000: Brijder 1991,
Brijder 2000: H. A. G. Brijder, Siana Cups III: The RedBlack Painter, Griffin-Bird Painter and Siana Cups Resembling Lip-Cups (Amsterdam 2000). no. 330 pl. 105d (Heidelberg P.); (c) Siana cup, once Zurich Market, Gallerie Nefer: Brijder 2000, 728 no. 11 pl. $251 \mathrm{a}$ (Heidelberg P.). It is not clear if there is a discus-thrower among the athletes shown on the Tyrrhenian amphora, Geneva MF156 ( $A B V$ 99,49; $C V A$ 2, pl. 43,1-4). From the decade 550-540 BC there are six more vases, five of which -four Siana cups and a cup-skyphos- are by the Heidelberg Painter: (a) Siana cup, Munich 7739: $A B V$ 64,28; Brijder 1991, no. 407 pl. 133d; (b) Siana cup, Paris, Cab. Méd. 314: ABV 65,41; Brijder 1991, no. 408 pl. 134b; (c) Siana cup, once Brussels, J. L. Theodor Coll.: Brijder 2000, 730 no. 22 pl. 254e; (d) Siana cup, once New York Market: Brijder 1991, no. 385 bis pl. 130b; (e) Cup-skyphos, Corinth CP-881: A. B. Brownlee, Attic Black-Figure from Corinth: I, Hesperia 56 (1987) $81-83$ no. $14 \mathrm{pl}$. 13. The sixth vase is a proto-A cup very close to Lydos (Athens, NM 445: ABV 113,83; Para 45 and 49; CVA 3 pl. 48,1, 4).

10. (a) Siana cup, Amsterdam 10.000: see above n. 9; (b) Siana cup, Thebes 6113 (R 49.261): $A B V 70,2$; $C V A$ 1, pl. 30,2 (Sandal P.); (c) Tyrrhenian amphora, Geneva MF156: see above n. 9. A newly published Siana cup fragment from Miletus, attributed to the Heidelberg Painter and showing an acontist, has been placed in the painter's late period, i.e. in the decade 550-540 BC (Miletus Z93.28.10 and 11: Brijder 2000,730 no. 25 pl. 254c). For early javelin-throwers see also the fragmentary dinos from the Athenian Acropolis (B. Graef, E. Langlotz, Die antiken Vasen von der Akropolis zu Athen I [Berlin 1925] no. 590 a-c pl. 27), a work of c. 560 BC, showing javelin-throwers at a mythical event, the Funeral Games for Pelias.

11. Amsterdam 10.000 (see n. 9). Two other pentathlon events, however, wrestling and boxing, are combined on several early Siana cups: see, e.g., Brijder 1983, no. 106 and no. 111 pl. 21 e-f (C P.); Brijder 1991, 482 no. 4 pl. 164d (Malibu P.); Brijder 1991, no. 406 pl. 132g (Heidelberg P.).

12. Of the four earliest vases depicting a discus-thrower three show him in exactly this pose: the Benaki cup discussed here, the Boeotian tripod pyxis in Berlin and the Siana cup in Amsterdam (see n. 9); also, of the later vases, the proto-A cup close to Lydos (see n. 9). For discus-throwing see E. N. Gardiner, Athletics of the Ancient World (Oxford 1930) 15468; J. Jüthner, Die athletischen Leibesübungen der Griechen II (Vienna 1968) 225-303; R. Patrucco, Lo sport nella Grecia antica (Florence 1972) 133-70; B. Legakis, Athletic Contests 
in Archaic Greek Art (Diss. Univ. Chicago 1977) 236-75; D. Vanhove a.o., Les disciplines sportives in: D. Vanhove (ed.), Le sport dans la Grèce antique. Du jeu à la compétition (exhibition catalogue, Palais des Beaux-Arts, Bruxelles, 23 Janvier-19 Avril 1992, Bruxelles 1992) 109-11.

13. This pose is favoured by the Heidelberg Painter; it occurs on one vase from the decade 560-550 BC (once Zurich Market: see n. 9) and on his five vases from the decade 550$540 \mathrm{BC}$ (see n. 9). On the cup once in Zurich and on the cup once on the New York Market the discus is held with the left hand!

14. See the comments by J. D. Beazley, The Development of Attic Black-Figure (Berkeley-Los Angeles 1951) 51.

15. For the technique of throwing the javelin in antiquity see Gardiner (n. 12) 169-76; Jüthner (n. 12) 307-50; Patrucco (n. 12) 171-89; Legakis (n. 12) 318-55; Vanhove (n. 12) 111 12.

16. C Painter: Brijder 1983, 127-28; Taras Painter: ibid. 161-62. By the Malibu Painter we have one horse-race (ibid. 176; cf. below n. 25), and three scenes with boxers and/or wrestlers: Brijder 1991, 482 no. 4 pl. 164d (wrestlers and boxers); Brijder 2000, 669, 723 no. 11 pl. $246 c$ (wrestlers); ibid. 669, 724 no. 18 pl. $246 \mathrm{~g}$ (boxers).

17. Brijder 1983, 127 with n. 179; id., Changing the Subject: Evidence on Siana Cups, in: H. A. G. Brijder (ed.), Ancient Greek and Related Pottery. Proceedings of the International Vase Symposium in Amsterdam, 12-15 April 1984 (Amsterdam 1984) 248-51; Brijder 1991, 391. For a statistical study see E. Goossens, S. Thielemans, The Popularity of Painting Sport Scenes on Attic Black and Red Figure Vases: A CVA-Based Research-Part A, BABesch 71 (1996) 59-94. On the development of sport in Athens and its significance in civic life see D. G. Kyle, Athletics in Ancient Athens (Leiden 1987); id., The Panathenaic Games: Sacred and Civic Athletics, in: J. Neils (ed.), Goddess and Polis. The Panathenaic Festival in Ancient Athens (Princeton 1992) 73-101; C. Mann, Athlet und Polis im archaischen und frühklassischen Griechenland (Göttingen 2001).

18. On the inauguration or reorganization of athletic games in the 6th century BC, see H. van Looy, Les festivals, in: Vanhove: (n. 12) 79-97; W. Decker, Sport in der griechischen Antike: vom minoischen Wettkampf bis zu den Olympischen Spielen (Munich 1995) 39-65.

19. On training in the gymnasium and the palaistra see O. Tzachou-Alexandri, The Gymnasium. An Institution for Athletes and Education, in: O. Tzachou-Alexandri (ed.), Mind and Body: Athletic Contests in Ancient Greece (exhibition catalogue, Athens, National Archaeological Museum, 15 May 1989-15 January 1990, Athens 1990) 31-40; Decker (op. cit.) 143-50; D. Vanhove, Le Gymnase, in: Vanhove (n. 12) $57-$ 77; Kyle, Athletics (n. 17) 141-45.

20. See, for example, the C Painter's cup Brijder 1983, no. 63 pl. $17 \mathrm{~d}$, or the Taras Painter's cups, ibid., no. 143 pl. 28d; no. 147 pl. 30 b; no. 157 pl. 30 d; no. 163 pl. 32a; no. 169 pl.
32 c-d; Brijder 2000, 720 no. 28 pl. 243d. On the Malibu Painter's cup once on the New York Market (Brijder 1991, 481-82 no. 1 pl. 164b) the man on the left raising his hand is very similar to the man standing in front of the horseman on the Benaki cup.

21. See Brijder 1983, 125, 127-28. On horse-racing see $\mathrm{H}$. A. Harris, Sport in Greece and Rome (London 1972) 151-71; Patrucco (n. 12) 373-403; D. Bell, The Horse Race (keles) in Ancient Greece from the Pre-Classical to the First Century B.C., Stadion 15 (1989) 167-90; E. Maul-Mandelarzt, Griechische Reiterdarstellungen in agonistischem Zusammenhang (Frankfurt 1990); Decker (n. 18) 105-15. A Siana cup once on the Freiburg Market (Brijder 2000, no. 642 pl. 210 b-c) shows on each side three youths galloping to the right flanked by huge tripods which confirm the agonistic character of this type of scene on Siana cups (see Maul-Mandelartz [op. cit.] 61-62). T. B. L. Webster, Potter and Patron in Classical Athens (London 1972) 181-82, does not exclude the possibility that riders with spears are also meant to be jockeys, since one of them appears on an amphora of Panathenaic shape next to a tripod (Bonn 589: $A B V$ 86,7; Maul-Mandelarzt [op. cit.] no. PS2 pl. 31).

22. Webster (n. 21) 182-87; Brijder 1983, 128 with n. 188 , 161; Maul-Mandelarzt (n. 21) 61 with n. 196.

23. Brijder 1983, 129, 162. The interpretation is largely due to the image of a victorious athlete carrying a tripod who is attended by similar gesticulating figures on a Siana cup by the C Painter in Heidelberg: $A B V 51,1$; Brijder 1983, no. 46; CVA 4, pl. 152,1.

24. C Painter: Brijder 1983, no. 86 pl. 20a; no. $89=C V A$ Toronto 1 pl. 31, 2-4; Taras Painter: ibid. no. 136 pl. 28c; no. 138; no. 148; no. 158 pl. 31a; no. 158 bis; no. 159; Brijder 1991, 480 no. 2 pl. 161c; no. 3; no. 6 pl. 162 a-c; Brijder 2000,719 no. 25 pl. 243 b; 720 no. 28 pl. 243 d; no. 36 ; no. 37.

25. Similarly rendered are the jockeys in the only horse-race by the Malibu Painter on a cup in Taranto: Para 24,57bis; Brijder 1983, no. 224 pl. 39a. Cf. a dressed rider on a fragment by the same painter from the Athenian Agora, possibly a jockey too ( $A B V 59,5$; Brijder 1983, no. 225). A rare instance of jockeys wearing chitoniskoi in the C Painter's work is the cup Brijder 1983, no. 89 (see n. 24).

26. See, e.g., Brijder 1983, pls 41f, 46a, 46e, 47a. Cf. the archer, ibid., pl. $47 \mathrm{~b}$ and his counterpart by the Taras Painter, ibid. pl. 36g. The running warrior on the interior of several cups by the C Painter and the Taras Painter does not look round.

27. New York, Atlantis Antiquities: Brijder 1991, 481-82 no. 1 pl. $165 \mathrm{e}$.

28. On such figures see $H$. van Wees, Greeks Bearing Arms, in: N. Fischer, H. van Wees (eds), Archaic Greece. New Approaches and New Evidence (London 1998) 352-58 with the earlier bibliography. 

44.

29. Brijder 1983, no. 140; C. Drago, NSc 1940, 351 fig.

30. Brijder 1983, no. 147 pl. 30 b.

31. See the fragmentary dinos from the Acropolis (n. 10) showing the Funeral Games for Pelias, a Siana cup fragment from Miletus (see n. 10; the leaf-shaped point of the javelin is just visible on the break of the fragment) and an amphora by the Amasis Painter with athletes shown above the main panel on side B (once Berlin 3210: ABV151,21; Papers on the Amasis Painter and his World [Malibu 1987] $101 \mathrm{fig}$. 2). The naked man throwing a spear on a red-figure lekythos of about 470 BC (Tzachou-Alexandri [n. 19] 266-68 no. 159) has been regarded as an athlete. For a detailed discussion of the form of the javelin shaft see Jüthner (n. 12) 309-13.

32. Height (as restored), 13.3-13.5 cm; height of lip and bowl $9 \mathrm{~cm}$; height of lip $2.6 \mathrm{~cm}$; diameter of rim 25.2-25.7 $\mathrm{cm}$; width across handles $32.4 \mathrm{~cm}$. Side B is illustrated in A. Delivorrias, D. Fotopoulos, Greece at the Benaki Museum (Athens 1997) 77 fig. 105 (colour ill.).

33. Letter of 1-2-1995. For the Painter of Boston C.A. see ABV 69; Para 28; J. Boardman, Athenian Black Figure Vases (London 1974) 33.

34. Thebes 25540: CVA 1 pls 31,1-4, 33,1-2, 34,2. For the subject see n. 22.

35. Cleveland 65.78: CVA 1 pls. 21, 22,2. The attribution to the same hand who painted the cup in Thebes is due to $\mathrm{V}$. Sabetai (CVA Thebes 1, 44, text to pl. 31) who named the painter "the Pyri Painter".

\section{For the subject see n. 21.}

37. The composition is quite similar to the image of runners trained by racing against horses as shown on some band-cups: see H. A. G. Brijder, CVA Amsterdam 2, 86-90 pl. 112; cf. the Siana cups, ibid., pl. 90 and Brijder 2000, 646, 698 no. 644.

38. For the subject see E. R. Young, The Slaying of the Minotaur. Evidence in Art and Literature for the Development of the Myth, 700-400 B.C. (Diss. Bryn Mawr 1972); P. J. Connor, The Painter of Villa Giulia 3559: Additions to his Work, BABesch 55 (1980) 29-34; F. Brommer, Theseus (Darmstadt 1982) 35-64; LIMC VI (1992) 574-81 s.v. Minotauros (S. Woodford); LIMCVII (1994) 940-43 s.v. Theseus (S. Woodford).

39. Thebes 6107: CVA 1 pls 32,1-2, 33,3-4; Athens NM 12586: CVA 3, pl. 20,1-3; once Basel Market: Connor (n. 38) 35 fig. 9. These cups belong to the decade 550-540 BC.
40. The Minotaur is shown confronting Theseus on the Benaki and ex-Basel Market cups (see n. 39).

41. For stones as the Minotaur's weapons see Connor (n. 38) 31.

42. The Minotaur is tailless on the Benaki cup, but has a tail on the Athens and ex-Basel Market cups (see n. 39). On the Siana cup in Thebes (see n. 39) the painter had not made up his mind: on one side the Minotaur has a tail, while on the other he does not!

43. See, for example, a slightly later amphora, close borh to Lydos and to Group E, in Malibu, Getty Museum 86.AE.80 (CVA 1, pl. 1)

44. B. Fellmann, Zur Deutung frühgriechischer Körperornamente, JdI 93 (1978) 1-29, regards them as signs of superhuman power; J. Boardman, An Anatomical Puzzle, $A A$ (1978) 330-33, sees them as mere representations of old wounds. On tattoo-marks see also K. Schauenburg, Ein Psykter aus dem Umkreis des Andokidesmalers, JdI 80 (1965) 80, 82 with n. 20; K. Zimmermann, Tätowierte Thrakerinnen auf griechischen Vasenbildern, $J d I 95$ (1980) 165 n. 6; A. Clark, CVA Malibu, Getty Museum 1, 51-52, text to pl. 50, 1-2.

45. On the subject see I. Scheibler, Dreifussträger, in: Kanon. Festschrift Ernst Berger (15. AntK-BH, Basel 1988)

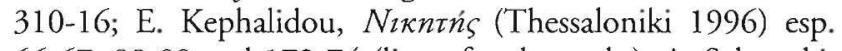
66-67, 88-89 and 172-74 (lists of early works); A. Sakowski, Darstellungen von Dreifusskesseln in der griechischen Kunst bis zum Beginn der klassischen Zeit (Frankfurt 1997) 92-94, 25456 (lists). For representations of victorious athletes see also Webster (n. 21) 152-57. For representations of tripods in art, Sakowski (op. cit.). For the meaning of the tripod, K. Schwendemann, Der Dreifuss, JdI 36 (1921) 98-185; for its evolution, S. Benton, The Evolution of the Tripod-Lebes, BSA 35 (1934-1935) 74-130; for tripods as prizes, Maul-Mandelarzt (n. 21) 53-54 n. 146; Kephalidou (op. cit.) 104-09; Sakowski (op. cit.) 82-106.

46. Heidelberg S1: See n. 23.

47. See, for example, an amphora in Rome, Villa Giulia 8340 (ABV 149,1; Scheibler [n. 45] pl. 88,2-3).

48. We should note here that the tripod carried on the $\mathrm{C}$ Painter's cup in Heidelberg (see n. 46) is also small in spite of the fact that there is plenty of space for a larger one.

49. See Maul-Mandelarzt (n. 21) 72 n. 247.

50. See Webster (n. 21) 152. 


\section{МАРІА ПІПІАН}

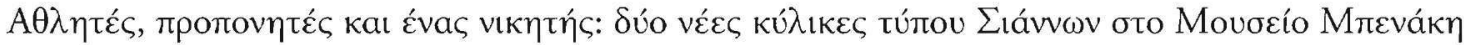

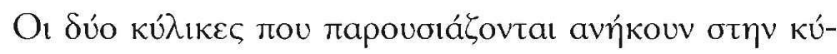

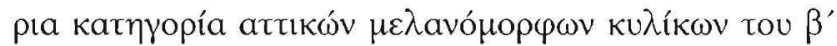

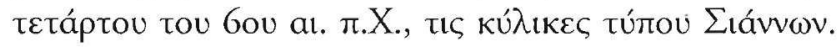

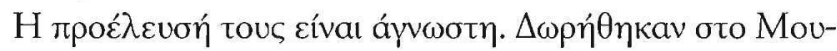

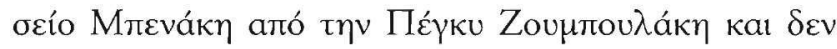

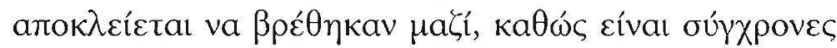

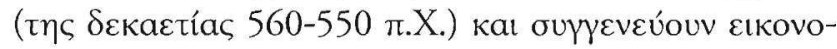

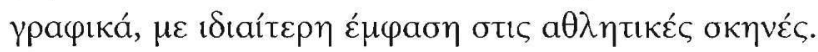

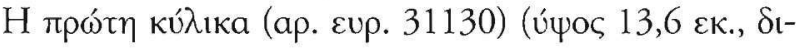

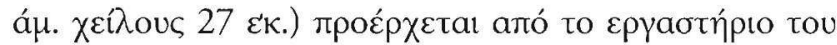

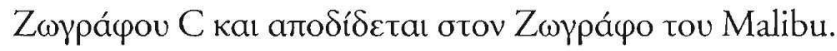

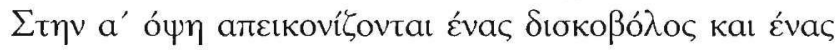

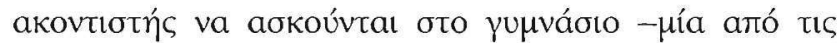

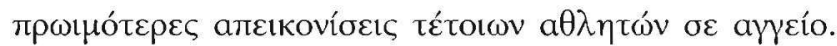

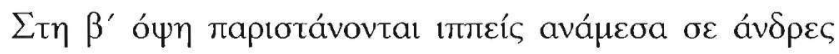

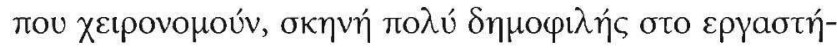

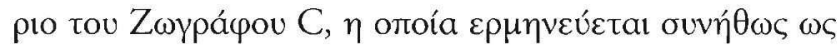

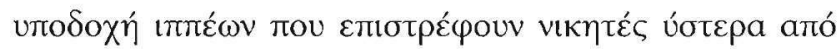

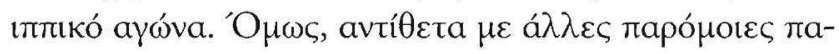

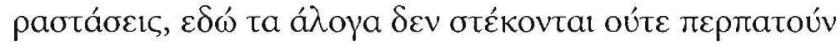

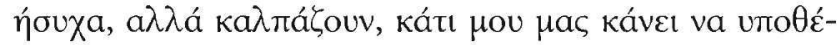

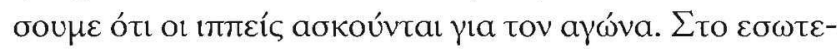

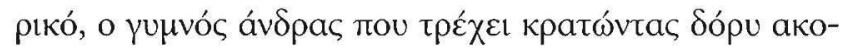

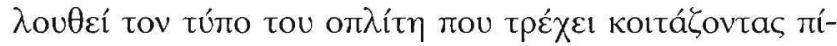

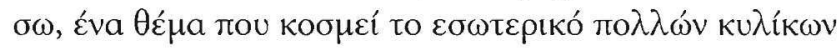

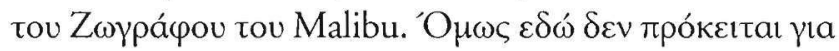

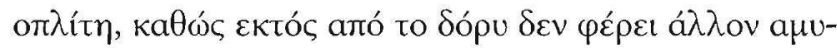

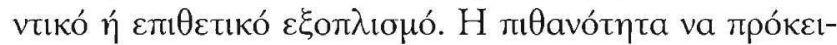

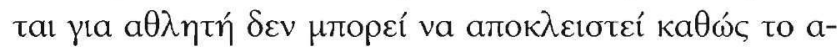

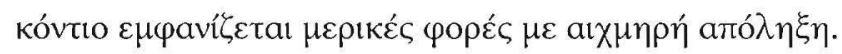

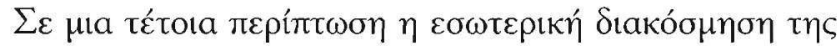

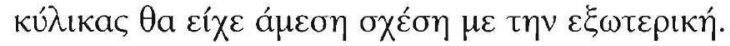

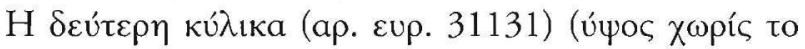

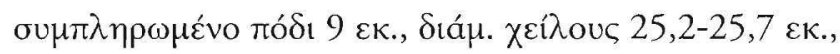

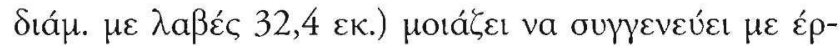

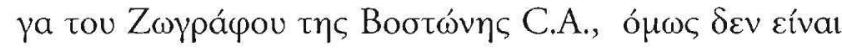

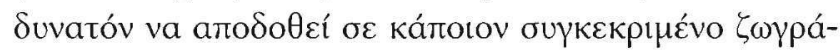

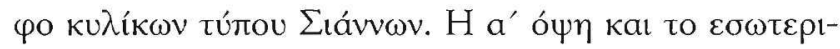

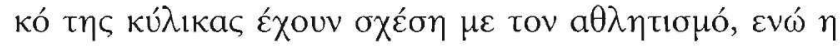

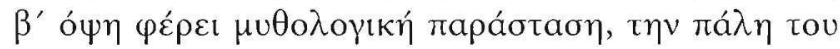

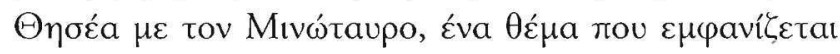

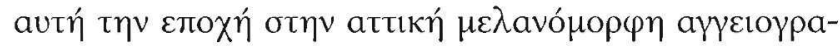

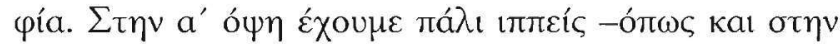

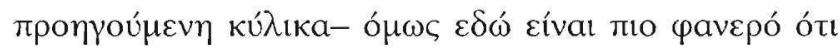

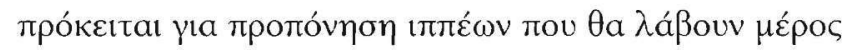

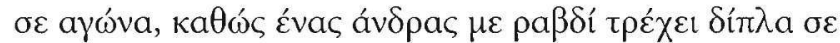

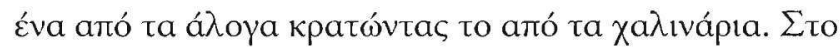

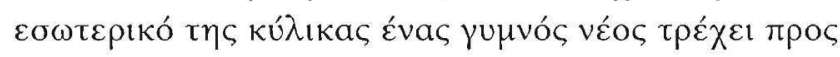

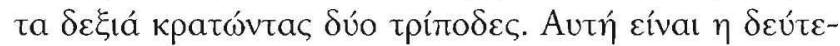

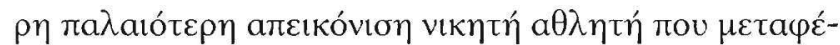

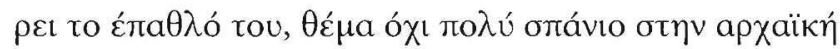

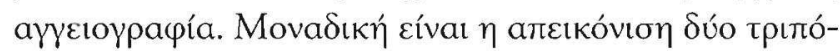

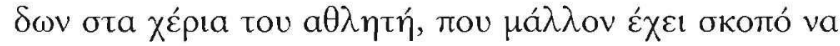

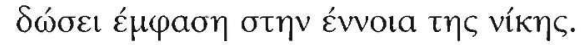

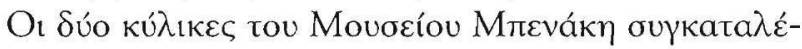

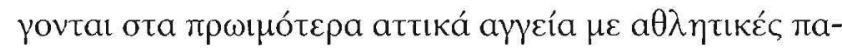

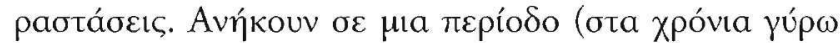

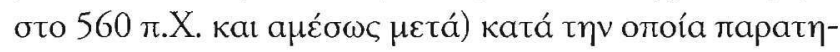

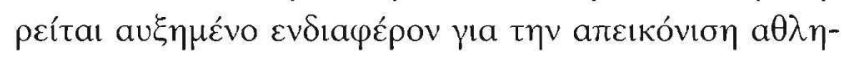

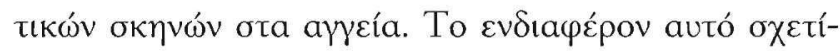

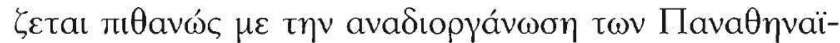

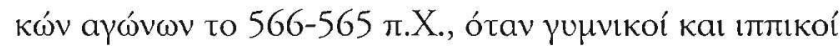

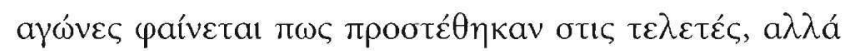

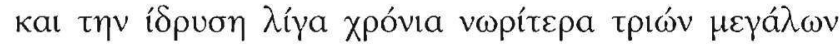

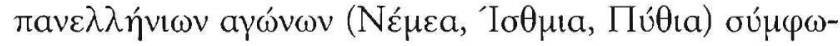

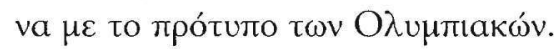

